\title{
Spontaneous Rhythmicity in Cultured Cell Clusters Isolated from Mouse Small Intestine
}

\author{
Shinsuke NAKAYAMA and Shigeko TORIHASHI \\ Department of Cell Physiology and * Department of Anatomy and Molecular Cell Biology, Nagoya University \\ Graduate School of Medicine, Nagoya, 466-8550 Japan
}

\begin{abstract}
To investigate spontaneous rhythmicity in smooth muscle tissue, we have developed a cell cluster preparation. Cell clusters were enzymatically isolated from the muscle layer of mouse small intestine and cultured for several days. They included smooth muscle, neurones, and c-Kit-immunopositive interstitial cells. c-Kit-immunopositive cells in myenteric plexus, showing a networklike structure, are putative pacemaker cells. The cultured cell clusters routinely show spontaneous contraction and preserve characteristic features in this tissue: (1) high temperature dependency of contractile frequency; (2) spontaneous electrical activities measured with patch clamp techniques are insensitive to tetradotoxin (TTX) and dihydropyridine $\mathrm{Ca}^{2+}$ antagonists. This preparation could therefore be used as a good model system to investigate the underlying mechanisms of intestinal
\end{abstract}

motility and pacemaker function. The relationship between the frequency of electrical activity and cluster size suggests that the minimum unit of small intestine tissue to yield normal pacemaker activity is approximately $100 \mu \mathrm{m}$ in diameter, or less. The applications of 100-120 $\mu \mathrm{M} \mathrm{Cd}^{2+}$ and $\mathrm{Ni}^{2+}$ significantly suppressed the spontaneous activity. $\mathrm{Ca}^{2+}$ influx pathways other than L-type and "classical" T-type voltage-sensitive $\mathrm{Ca}^{2+}$ channels seem very likely to play an important role, such as nonselective cation channels and capacitative $\mathrm{Ca}^{2+}$ entry. Furthermore, applications of heptanol reduced the amplitude and the frequency of the oscillating inward currents and eventually terminated them, suggesting that electrical cell-to-cell coupling may also make some contribution to the generation of spontaneous activity. [Japanese Journal of Physiology, 52, 217-227, 2002]

Key words: slow waves, smooth muscle, intestinal motility, c-Kit immunoreactivity, interstitial cells of Cajal.

Gastrointestinal tract motility is driven by slow electrical oscillation, so-called slow waves [1-4], and is modulated by autonomic nervous activity, such as releases of local hormones. Smooth muscle tissues, even when isolated, still show such slow electrical oscillation. Thus slow waves are regarded as the basic rhythm of the intestinal motility caused by endogenous mechanisms.

Recently, lines of evidence have been presented to show that c-Kit-immunopositive interstitial cells (ICC: interstitial cells of Cajal) included in the myenteric plexus play an important role in generating slow waves. First, slow waves are not observed in the in- testinal tract of $\mathrm{W} / \mathrm{W}_{\mathrm{V}}$ mice in which the development of interstitial cells, especially in the myenteric plexus region, is prevented because of the low tyrosine kinase activity of c-Kit [5-7]. Second, isolated c-Kit-positive interstitial cells from the murine intestine show spontaneous electrical activities [8-10]. Furthermore, in some other tissues in upper and lower urinary tracts, ICC-like cells have been suggested to play the role of a pacemaker $[11,12]$.

In our preliminary experiments, we enzymatically isolated intestinal cells from the muscle layer and cultured them for several days. These cells, even with cKit immunoreactivity, seldom produce regular electri-

Received on December 25, 2001; accepted on March 25, 2002

Correspondence should be addressed to: Shinsuke Nakayama, Department of Cell Physiology, Nagoya University Graduate School of Medicine, Tsuruma 65, Showa-ku, Nagoya, 466-8550 Japan. Tel: +81-52-744-2045, Fax: +81-52-744-2048, E-mail: h44673a@nucc.cc.nagoya-u.ac.jp 
cal oscillation such as slow waves. On the same culture dishes, we also observed that many small cell clusters were spontaneously contracting. These observations suggested a hypothesis that slow waves are stably generated when several intestinal cells of essential members are properly assembled. In the present study, we therefore examined the properties of spontaneous electrical activity in cultured cell clusters. This preparation consisted of smooth muscle, neurones, and c-Kit-immunopositive interstitial cells. Using patch clamp techniques, we found that cell clusters of approximately $100 \mu \mathrm{m}$ diameter or less produced electrical oscillations whose properties mimicked those seen in the intact tissue. Also, the effect of temperature on contractility was investigated with digital video camera systems. It would appear that these cell cluster preparations may link studies performed in isolated intestinal cells and intact tissues.

\section{METHODS}

\section{Preparation of cultured cells and cell clus-}

ters. The animals used in the present study were treated ethically according to the Guidelines for the Care and Use of Animals approved by the Physiological Society of Japan. BALB/c mice (10-20 d after birth) of both sexes were sacrificed by cervical dislocation, and the small intestine ( $5 \mathrm{~cm}$ length) was immediately dissected. The smooth muscle layer (both circular and longitudinal layers) and the myenteric plexus were carefully removed and cut into small pieces (1-2 mm long).

The small muscle pieces were incubated in $\mathrm{Ca}^{2+}$ free Hanks' solution containing collagenase $(1.3 \mathrm{mg} /$ ml, No 034-10533; Wako Chemical, Osaka, Japan), trypsin inhibitors ( $2 \mathrm{mg} / \mathrm{ml}$, type I-S; Sigma, St Louis, MO, USA), ATP $(0.27 \mathrm{mg} / \mathrm{ml}$, Seikagakukogyo, Tokyo, Japan), and bovine serum albumin $(2 \mathrm{mg} / \mathrm{ml}$, Sigma) for $35-45 \mathrm{~min}\left(37^{\circ} \mathrm{C}\right)$. After being rinsed with enzyme-free $\mathrm{Ca}^{2+}$-free solution (containing neither collagenase nor trypsin inhibitors), the muscle pieces were triturated with fire-blunted glass pipettes. The resultant small cell clusters were placed on a lab-made culture dish (a silicone ring approximately $20 \mathrm{~mm}$ in diameter on a cover glass $25 \mathrm{~mm}$ in diameter and $0.12-0.17 \mathrm{~mm}$ thick, coated with mouse collagen) and kept in Dalbecco's modified Eagle's medium (Life Technologies, Inc., Rockville, MD, USA) supplemented with $10 \%$ foetal bovine serum (Sigma) and antibiotics (streptomycin $[30 \mu \mathrm{g} / \mathrm{ml}]$ and penicillin [30 units/ml]; Life Technologies). The cover glass (Micro Cover Glass) was purchased from Matsunami (Osaka, Japan). When these isolation methods were appropri- ate, most cell clusters in a culture dish showed spontaneous contraction. (We sometimes obtained no clusters showing spontaneous contractions, even though the same isolation methods were apparently applied. Such preparations were discarded, assuming the digestion to be too advanced.)

Measurements of contractile and electrical activities. The culture dish was mounted on a warming glass plate (DC-MP10DM; Kitazato Supply Ltd., Fujinomiya, Japan), and the cell clusters were equilibrated in normal solution for 15-30 min before measurements. In some cell clusters, contractile activities were recorded with digital video camera systems (ARGUS HiSCa [Hamamatsu Photonics, Hamamatsu, Japan] or MTV6368 combined with GV-D800 [SONY, Tokyo, Japan]), and the effect of changing temperature on the frequency of spontaneous contraction was examined.

In the cells near the edge of the clusters showing spontaneous contraction, membrane currents were measured in voltage-clamp mode with a patch clamp amplifier (Axopatch 200A: Axon Instruments, Foster City, CA, USA), and digitized through an $\mathrm{AD} / \mathrm{DA}$ converter (TL-1; Axon Instruments). A cutoff frequency of $2 \mathrm{kHz}$ was applied to reduce the noise. The resistance of the patch pipette was $2.5-5 \mathrm{M} \Omega$, when a $\mathrm{K}^{+}$-rich pipette solution was used. Unless otherwise described, the cell membrane was clamped at $-60 \mathrm{mV}$. Most electrical recordings were carried out at $35^{\circ} \mathrm{C}$.

In preliminary experiments, whole-cell membrane currents were also recorded (at $35^{\circ} \mathrm{C}$ ) from isolated cells, which were obtained together with small cell clusters in the enzymatic isolation procedure described above. In some isolated cells, c-Kit-immunoreactivity was examined (see the Immunohistochemistry and electron microscopy section).

The composition of a normal bathing solution was as follows (mM): $\mathrm{NaCl}, 125 ; \mathrm{KCl}, 5.9 ; \mathrm{CaCl}_{2}, 2.5 ; \mathrm{MgCl}_{2}$, 1.2; glucose, 11.8, and HEPES, 11.8; $\mathrm{pH}$ adjusted to 7.4 with Tris base. The composition of the pipette solution was (mM): K-aspartate, $110 ; \mathrm{KCl}, 20 ; \mathrm{MgCl}_{2}$, 4; EGTA (ethyleneglycol-bis-( $\beta$-aminoethylether) $N, N, N^{\prime}, N^{\prime}$-tetraacetic acid), 0.1 ; ATP, 4; GTP, 0.1; HEPES, 20 (pH 7.2). The chemicals used were ATP (disodium salt) and GTP (trisodium salt) from Seikagakukogyo, EGTA (free acid), 1-heptanol, tetrodotoxin (TTX), and nifedipine from Sigma.

Immunohistochemistry and electron microscopy. To identify c-Kit-immunopositive cells, the cultured cell cluster preparations were treated with anti-c-Kit antibody (ACK2, $10 \mu \mathrm{l} / \mathrm{ml}$ ) [7] conjugated with Alexa Fluoro 594 (Molecular Probes, Eugene, 
OR, USA) for $5 \mathrm{~min}$. Subsequently, the preparations were washed with normal solution, and fixed with acetone at $4^{\circ} \mathrm{C}$. For an examination of actin immunoreactivity, anti- $\gamma$-enteric actin antibody $(1: 200$; ICN, Costa Mesa, CA, USA) was used as a primary antibody after acetone fixation. When the distribution of gap junction channels was examined, cell clusters were fixed with methanol for $10 \mathrm{~min}\left(\right.$ at $\left.4^{\circ} \mathrm{C}\right)$ and treated with anti-connexin-43 antibody $(1: 10$; Transduction Lab, Lexington, KY, USA) as a primary antibody. Subsequently, the clusters were washed with $10 \mathrm{mM}$ PBS (phosphate buffered saline, $\mathrm{pH}$ 7.4) and incubated with fluorescein isothiocyanate (FITC)conjugated anti-mouse IgG $(1: 100)$. The same procedure was applied to stain gap junction channels in intact circular muscle layer. Also, absorption tests were carried out by the use of connexin-43 antigen (Transduction Lab) in both cell clusters and intact circular muscle preparations. Few nonspecific fluorescent signals were detected. The immunoreactivity was examined with a confocal laser microscope (MRC 1024; BIO-RAD, UK). Phase contrast and nomarski micrographs were obtained with a conventional microscope (Axiovert 25; Carl Zeiss, Heidelberg, Germany).

In electronmicroscopy, the cell cluster preparations were fixed for $30 \mathrm{~min}$ with cacodylate buffer $(50 \mathrm{mM}$, $\mathrm{pH}$ 7.4) containing $2.5 \%$ glutaraldehyde, $1.25 \mathrm{mM}$ $\mathrm{CaCl}_{2}$, and $3 \%$ sucrose. The clusters were then postfixed with $\mathrm{OsO}_{4}$ in the same buffer and block-stained with saturated uranyl acetate in distilled water. Subsequently the cluster samples were dehydrated with ethanol and embedded in epoxy resin. Semithin sections $(1 \mu \mathrm{m}$ thick) were stained with $2 \%$ toluidine blue in $0.1 \mathrm{M}$ phosphate buffer (pH 7.4). Ultrasections were double-stained with uranyl acetate and lead citrate, then examined with a transmission electron microscope (H-7100; Hitachi, Tokyo, Japan).

Statistics. Numerical data are expressed as mean \pm standard deviation (SD). Differences between means were evaluated by paired $t$-tests. $p$ values of less than 0.05 were taken to indicate statistically significant differences. Pearson's regression coefficients $(r)$ are quoted in regression analyses.

\section{RESULTS}

\section{Cultured cell cluster preparation}

On the first day of culture, some cells near the edge of the cell cluster adhered to the culture dish (made of a thin cover glass and silicone ring). When enzymatic isolation was appropriate, spontaneous rhythmic contraction was seen in most cell clusters and lasted up to several days. Figure 1A shows an example of such a cell cluster. The contractility observed under a microscope in conjunction with a digital video camera system, had clear temperature dependency. As shown in Fig. 1B, 20 of 24 clusters tested (in three culture dishes) showed spontaneous periodic contraction with a frequency of $6.2 \pm 2.5 \mathrm{cycles} / \mathrm{min}$ at $30^{\circ} \mathrm{C}$. After the temperature of the warming glass plate had been increased to $35^{\circ} \mathrm{C}$ for $20 \mathrm{~min}$, the number of cell clusters showing spontaneous contraction increased ( 22 of 24 ), with a statistically significant increase of the average frequency (12.3 \pm 4.4 cycles $/ \mathrm{min})$.

\section{Cell members and structure of the cluster}

Figure 2A and B show phase-contrast and confocal fluorescent micrographs obtained from the same cell

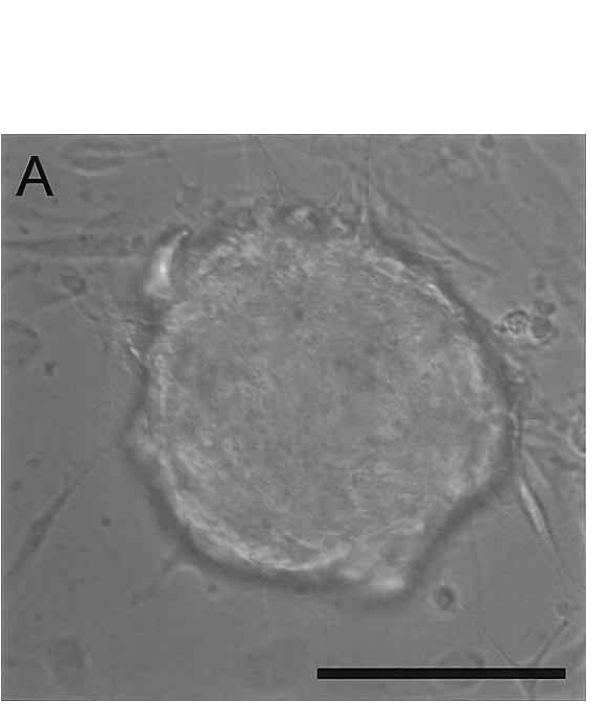

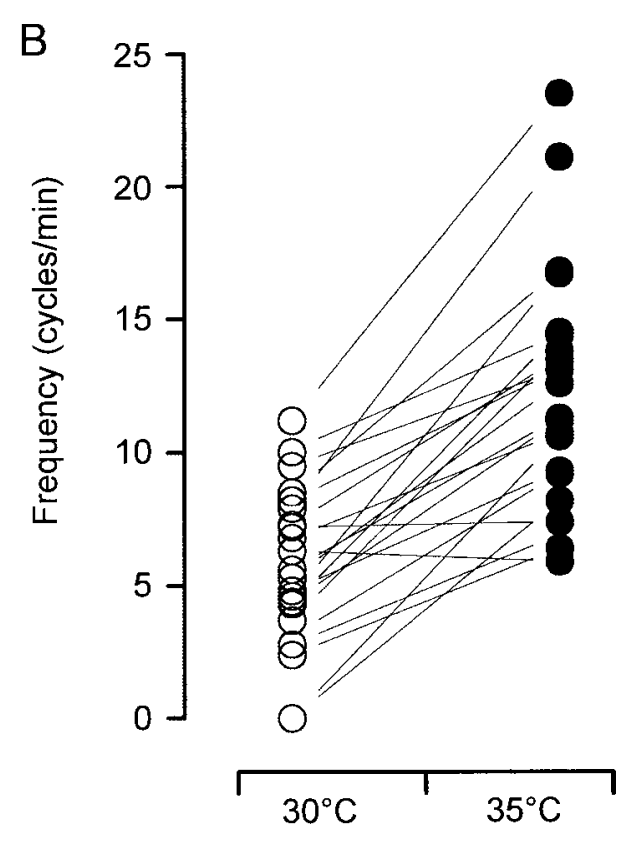

Fig. 1. Cultured cell cluster preparation isolated from murine small intestine. A: Transmission image of an example cell cluster that shows spontaneous contraction under a light-microscope (phase-contrast) in conjunction with a digital video camera. Scale bar, $100 \mu \mathrm{m}$. B: Graph showing effects of changing temperature on spontaneous contraction. In 24 individual cell clusters (in three culture dishes), the frequency (cycles/min) of spontaneous contraction is compared at 30 and $35^{\circ} \mathrm{C}$. The data point at frequency $=0$ cycles $/ \mathrm{min}$ corresponds to two cell clusters with no spontaneous activity at $30^{\circ} \mathrm{C}$. 

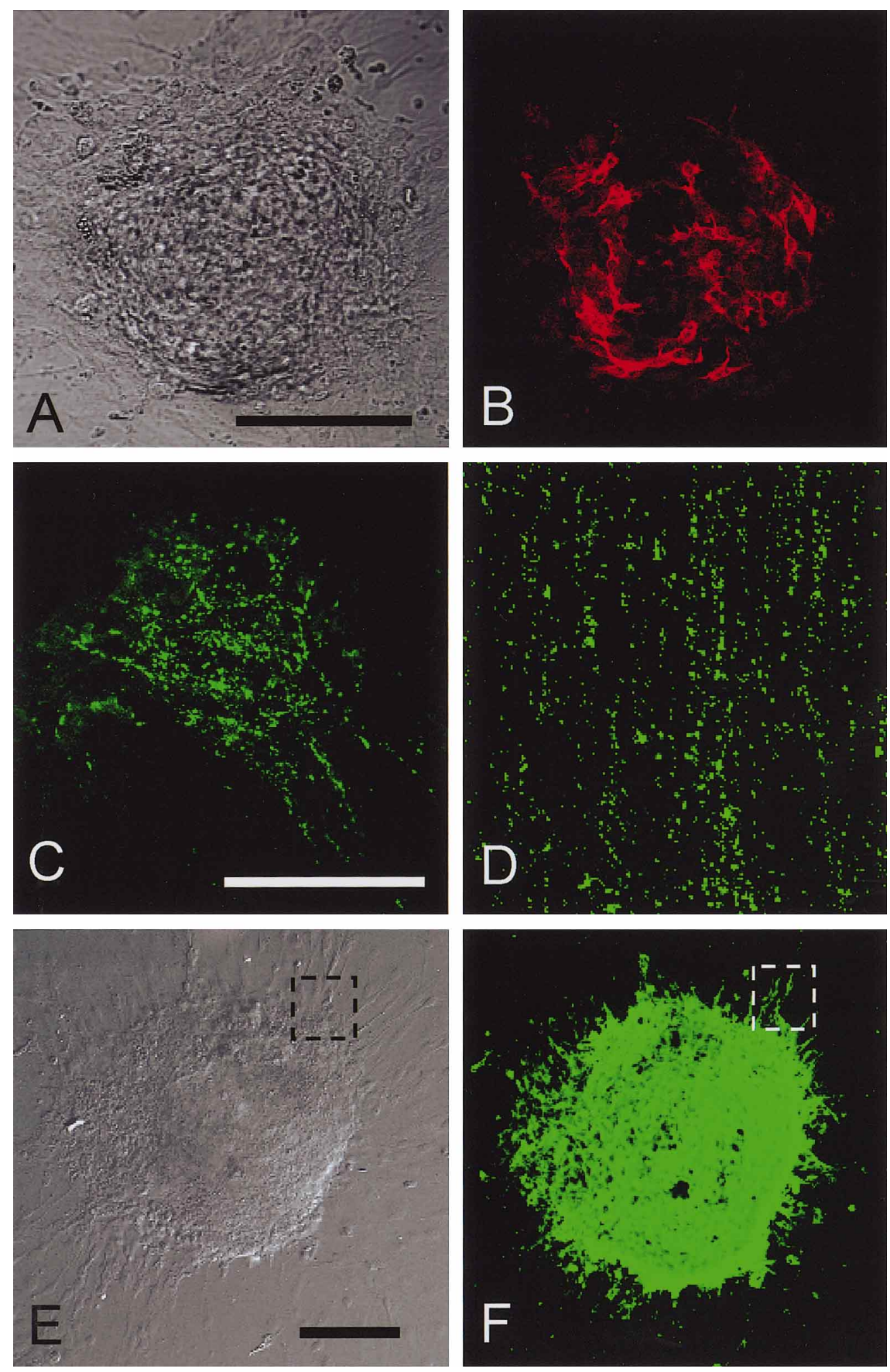

Fig. 2. Conventional and confocal micrographs of cell clusters cultured $\mathbf{2}$ to $\mathbf{3} \mathbf{d}$. Phase-contrast micrograph showing a cell cluster (A). c-Kit immunoreactivity (B: confocal micrograph of ACK2 conjugated with Alexa Fluoro 594) was observed from the same cluster shown in A. The cKit-immunopositive cells are in contact with one another making a network. However, their distribution is irregular in comparison with that in intact tissue. The magnification of $B$ is the same as $A$ (bar $=100 \mu \mathrm{m}$ for both A and B). Confocal micrographs showing a distribution of gap junctions stained with anti-connexin-43 antibody in a cell cluster (C) and a wholemount preparation of circular muscle layer of small intestine (D). In both micrographs, immunoreactivity is distributed throughout the cell cluster as fine granules (bar $=50 \mu \mathrm{m}$ for both $\mathrm{C}$ and D). A Nomarski image (E) and a confocal micrograph showing anti- $\boldsymbol{\gamma}$-enteric actin immunostaining $(\mathbf{F})$ were obtained from the same cell cluster. The dashed squares indicate the region from which electrical activities were recorded in Fig. 4A (bar $=50 \mu \mathrm{m}$ for both $\mathrm{E}$ and $\mathrm{F}$ ). cluster. In Fig. 2B, the cluster was stained with an ACK2 conjugated with a fluorescent dye (Alexa Fluoro 594). This confocal micrograph demonstrates networks of c-Kit-immunopositive interstitial cells. The structure is similar to that of ICC in the myenteric region (IC-MY), putative pacemaker cells in the gastrointestinal tract. (There are two types of c-Kit-immunopositive cells found in the murine small intestine: ICC in the myenteric plexus region (IC-MY) and in the deep muscular plexus region (IC-DMP), but in the latter the population is minor.) Most cell clusters stained with the same procedure showed similar net- work structures. Figure $2 \mathrm{C}$ shows a confocal micrograph obtained from another cell cluster stained with an anti-conexin-43 antibody, suggesting that the cells included in the cluster were electrically connected via gap junction channels. On the other hand, the confocal micrograph in Fig. 2D shows the distribution of connexin-43 in a whole-mount preparation of circular muscle layer of mouse small intestine. The immunoreactivity of gap junction channels shows a similar distribution in intact and in cultured tissues and suggests that the procedure of culturing cell clusters in the present study did not substantially affect the channels. 

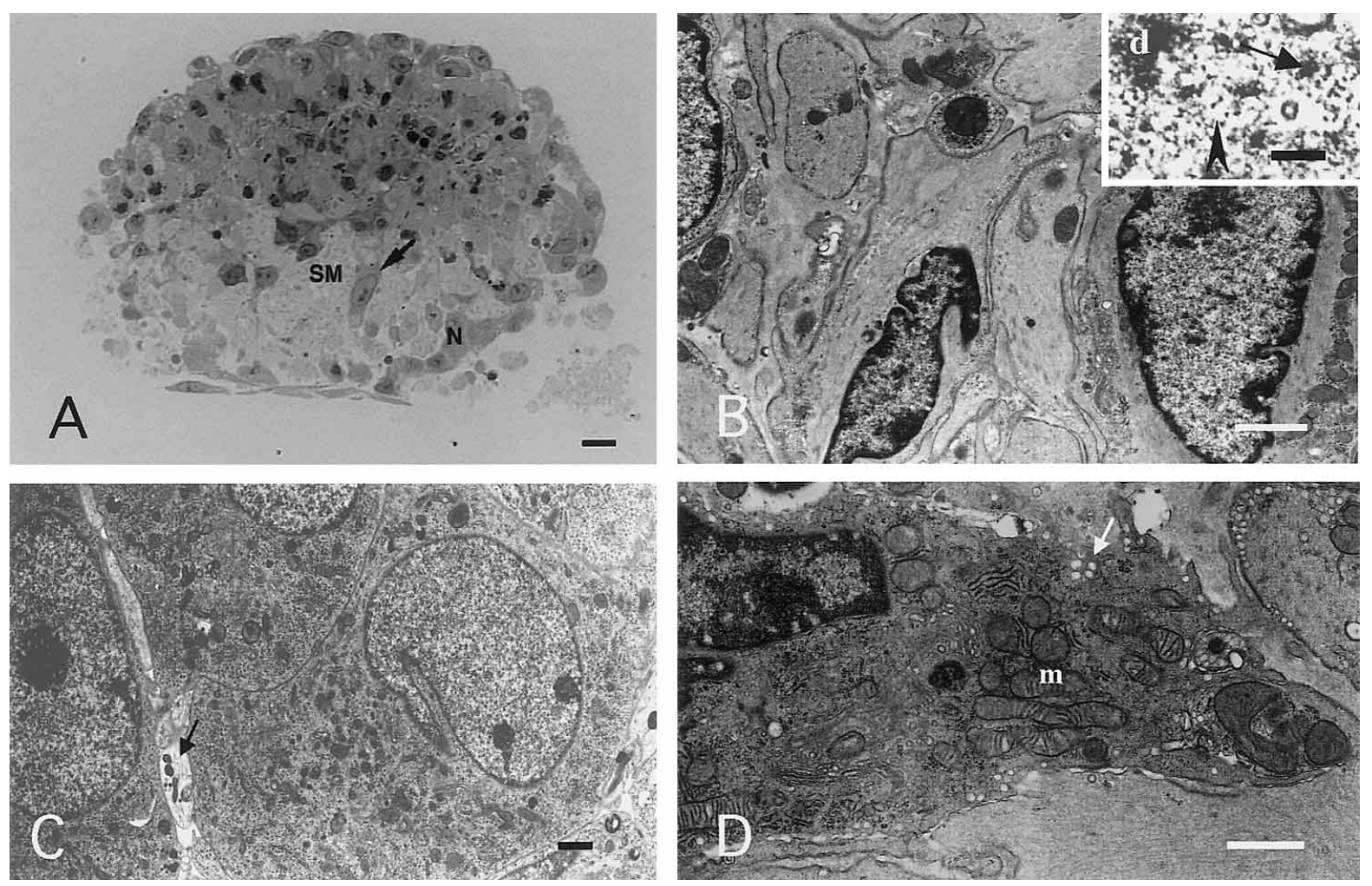

Fig. 3. Semithin section stained with toluidine blue (A) and electronmicrographs (B-D) of a cell cluster. The cluster shown in (A) includes round and spindle-shaped cells. The letters $\mathrm{N}$ and SM indicate neurones and smooth muscle cells, respectively, and the arrow indicates an interstitial cell. The electronmicrograph (B) shows smooth muscle cells (the same cells as indicated by SM in A) containing thin, thick myofilaments, dense bodies (arrowhead, arrow,

The nomarski and confocal micrographs shown in Fig. 2E and $\mathrm{F}$ were obtained from the same cell cluster, which were also used in the electrical recording shown in Fig. 4A. In Fig. 2F, the cell cluster was stained with anti- $\gamma$-enteric actin antibody. The dashed squares in Fig. $2 \mathrm{E}$ and $\mathrm{F}$ indicate the region from which electrical activities were recorded.

Figure $3 \mathrm{~A}$ shows a semithin section $(1 \mu \mathrm{m}$ thick) of a cell cluster stained with toluidine blue. Along with interstitial cells (arrow), smooth muscle cells (SM) and neurones $(\mathrm{N})$ were included in the cluster. These two types of cells (i.e., smooth muscle cells and neurones) were observed in most cell clusters examined. Figure 3B-D show electronmicrographs obtained from the smooth muscle, enteric neurones, and the interstitial cell indicated by SM, N, and the arrow, respectively, in Fig. 3A. Smooth muscle cells are full of thin and thick myofilaments and have dense bodies (Fig. 3B, insert), and enteric neurones have large nuclei and cell somas (Fig. 3C). The arrow in $\mathrm{C}$ indicates nerve fibers. On the other hand, in Fig. 3D the interstitial cell is characterized by its electron-dense

and $d$ respectively, in inset), and mitochondria. The enteric neurone (indicated by $\mathrm{N}$ in $\mathrm{A}$ ) has a large nucleus and cell soma $(\mathbf{C})$. Nerve fibers are indicated by the arrow in C. The electron micrograph of an interstitial cell (D) (indicated by the arrow in A) has electron-dense cytoplasm with several of mitochondria $(\mathrm{m})$ and caveolae (arrow in D). Bar $=10 \mu \mathrm{m}$ in $A, b a r=1 \mu \mathrm{m}$ in $B-D, b a r=100 \mathrm{~nm}$ in the inset $B$.

cytoplasm with numerous mitochondria (m) and caveola (arrow). In some cell clusters, the distribution of neurones was also verified by the immunoreactivity of anti-PGP9.5 antibodies (not shown).

\section{Inward current oscillation}

Whole-cell patch clamp techniques were applied to the intestinal cells near the edge of the cell clusters. As shown in Fig. 2F, these cells were mostly smooth muscle. The patch pipettes were filled with a $\mathrm{K}^{+}$-rich solution, and a holding potential of $-60 \mathrm{mV}$ was normally applied. In the cells examined at $35^{\circ} \mathrm{C}$, oscillating inward currents were reproduced with substantially constant intervals. Figure 4A shows an example of such oscillating inward currents, recorded from a smooth muscle cell in the dashed square in Fig. 2F. The frequency of the oscillating inward currents ranged from 9.8 to $27.6 \mathrm{cycles} / \mathrm{min}$ in 34 cells (average of $16.6 \pm 3.7$ cycles $/ \mathrm{min}$ ), and amplitudes varied from 99 to $2,704 \mathrm{pA}$ at $-60 \mathrm{mV}$ (average of $644 \pm 566 \mathrm{pA}, n=34)$. It appeared that the inward currents recorded from the cells at the far end of the clus- 
ter were smaller in amplitude. When more than two cells were examined in the same cluster, they showed nearly the same frequency of inward current oscillation, even though their amplitudes differed greatly. The duration of the half-maximal amplitude of the oscillating inward current $\left(\mathrm{ICD}_{50}\right)$ was $1,107 \pm 502 \mathrm{~ms}$ $(n=34)$. In whole-cell membrane current recordings, the input resistance was $23.0 \pm 9.5 \mathrm{M} \Omega(n=17)$ and seemed not to be correlated $(p>0.05)$ with the inward current amplitude. Moreover, the resting potential measured in current-clamp mode, or by an adjustment of the holding potential to zero current level in voltage-clamp mode, ranged from -40 to $-68 \mathrm{mV}$ with an average of $-54.5 \pm 6.7 \mathrm{mV}(n=29)$.

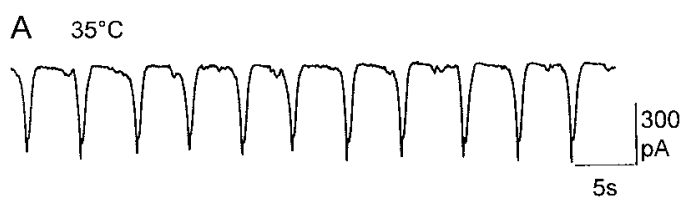

B Room temperature

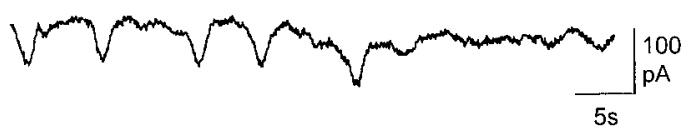

Fig. 4. Inward current oscillation recorded from cell clusters at $35^{\circ} \mathrm{C}(\mathrm{A})$ and room temperature (approximately $25-27^{\circ} \mathbf{C}$ ) (B). Whole-cell voltage clamp techniques were applied to intestinal cells included in cultured cell clusters. Holding potential: $-60 \mathrm{mV}$. The current trace (A) was obtained from a cell in the dashed square indicated in Fig. 2E and F.
When whole-cell recording was carried out at room temperature, only a few cells showed inward current oscillation, but the interval of the oscillating inward currents was irregular and its amplitude smaller (Fig. 4B). Spontaneous contractions were not normally observed at room temperature. The experiments examining the effects of various drugs, described below, were thus carried out in warmed solutions $\left(\right.$ at $35^{\circ} \mathrm{C}$ ).

Figure 5A shows the relationship between the oscillation frequency and the size of clusters $\left(\mathrm{mm}^{2}\right)$. The small correlation coefficient $(r=0.064, n=26$, Table 1) suggests that intestinal cell organizations of less than $100 \mu \mathrm{m}$ diameter generate spontaneous rhythmicity, essentially the same as intact tissues do. Also, neither the resting membrane potential $(r=0.222$, $n=29)$ nor the amplitude of the inward current $(r=0.156, n=34)$ was correlated with the oscillation frequency. On the other hand, the $\mathrm{ICD}_{50}$ seemed to be correlated with the oscillation frequency (with a rather

Table 1. Pearson's correlation coefficient $(r)$ between the frequency of oscillating inward current and various parameters.

\begin{tabular}{lcccc}
\hline & $\begin{array}{c}\text { Cluster } \\
\text { size }\end{array}$ & $\begin{array}{c}\text { Membrane } \\
\text { potential }\end{array}$ & $\begin{array}{c}\text { Current } \\
\text { amplitude }\end{array}$ & $\mathrm{ICD}_{50}$ \\
\hline$r$ & 0.064 & 0.222 & 0.156 & -0.409 \\
$n$ & 26 & 29 & 34 & 34 \\
$p$ value & 0.755 & 0.248 & 0.377 & 0.016 \\
\hline
\end{tabular}

$I C D_{50}$ indicates the duration of the half-maximal amplitude of the oscillating inward current.

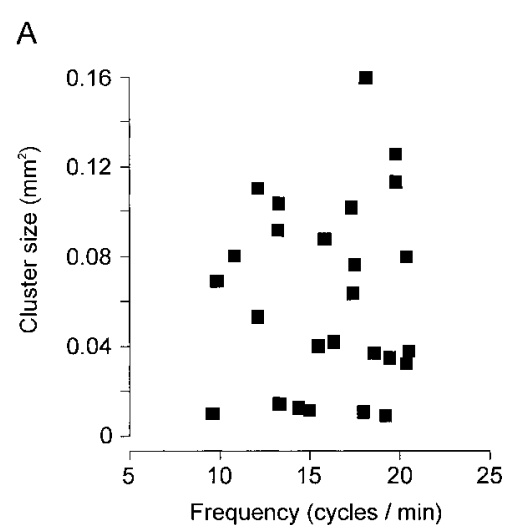

B

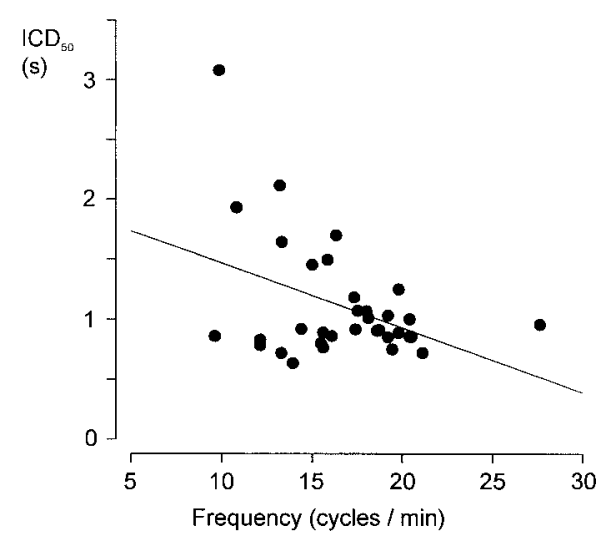

Fig. 5. Correlation plot showing the characteristics of inward current oscillation in cultured cell clusters. The data points are based on the recordings carried out in a normal solution at $35^{\circ} \mathrm{C}$. In $\mathbf{A}$, the relationship between the frequency of inward current oscillation (cycles/min, $x$-axis) and the size of the cell cluster $\left(\mathrm{mm}^{2}, y\right.$ axis) is shown. The area of the cell cluster was estimated as an oval: $\pi X Y / 4$, where $X$ and $Y$ are the major and minor axes of an oval, respectively. The Pearson's correlation coefficient ( $r$ ) was $0.064(n=26)$. In $\mathbf{B}$, the relationship between the frequency (cycles/min, $x$-axis) and the duration of the half maximal amplitude of the oscillating inward current $\left(\mathrm{ICD}_{50}\right)$ (ms, $y$-axis) is shown. The two parameters seem to weakly correlate with each other $(r=-0.409, n=34)$. The straight line indicates a regression line $(y=-54 x+2,003)$ 


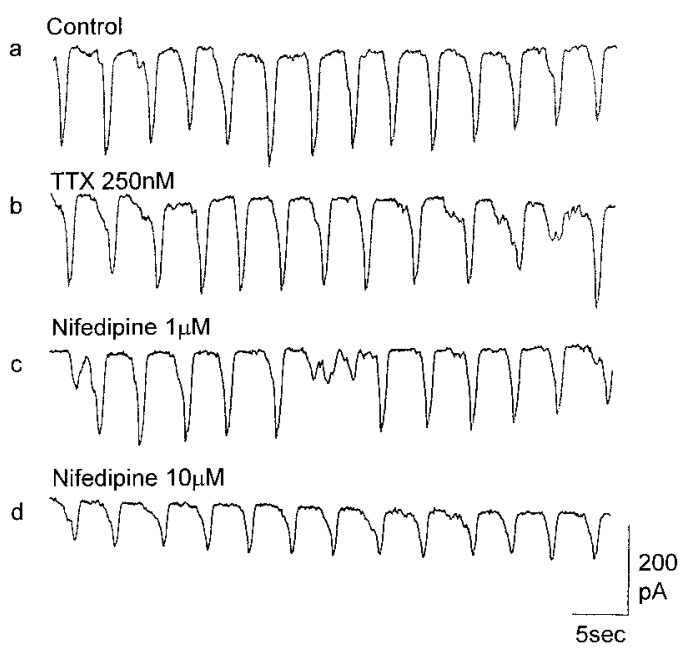

Fig. 6. Effects of TTX and nifedipine on inward current oscillation. After observing control membrane current oscillations (a), 250 nM TTX was applied (b). Subsequently, nifedipine ( 1 and $10 \mu \mathrm{M})$ was added in the presence of TTX (c and $\mathbf{d}$, respectively). Holding potential: $-60 \mathrm{mV}$; temperature: $35^{\circ} \mathrm{C}$.

low $r$ of $-0.409, n=34$, Fig. 5B) by a mechanism that remains to be determined. Furthermore, the cell clusters used for the experiments on spontaneous contractile activity (Fig. 2) showed no significant correlation between contraction frequency and cluster size, being consistent with the membrane current analysis (Fig. $5 \mathrm{~A})$.

\section{Effects of various channel blockers}

To investigate the underlying mechanisms of the inward current oscillation, voltage-sensitive $\mathrm{Na}^{+}$and $\mathrm{Ca}^{2+}$ channel blockers were examined. Figure 6 shows an example of these experiments. After observing control oscillating inward currents (a), an application of $250 \mathrm{nM}$ TTX, which would completely block nervous $\mathrm{Na}^{+}$channels, little affected the oscillating inward currents (b). Similar results were obtained from two other cells: on average $(n=3)$, the amplitude, frequency, and $\mathrm{ICD}_{50}$ were altered only to $101.5 \pm 9.0$, $99.3 \pm 5.8$, and $104.9 \pm 11.7 \%$, respectively. These results suggested that this oscillation is not due to periodic activation of excitatory nerves in the cell clusters. Furthermore, in one cell cluster $10 \mu \mathrm{M}$ atropine little affected the inward current oscillation. A current trace (c) shows an additional application of $1 \mu \mathrm{M}$ nifedipine in the presence of TTX. This concentration is significantly greater than the $\mathrm{IC}_{50}$ value for smooth muscle L-type $\mathrm{Ca}^{2+}$ channels (e.g., $\left.[13,14]\right)$, which provides sustained $\mathrm{Ca}^{2+}$ influx during the depolarization phase of slow waves [15]. In five cells (including absence and presence of TTX), an application of nifedipine $(1 \mu \mathrm{M})$ changed the amplitude and frequency by only
A
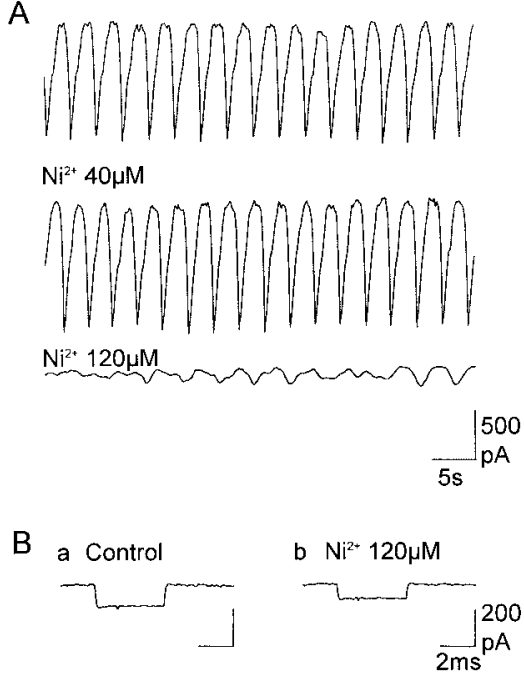

Fig. 7. The effects of $\mathrm{Ni}^{2+}$ on inward current oscillation. In (A), $\mathrm{NiCl}_{2}$ (middle, $40 \mu \mathrm{M}$; lower, $120 \mu \mathrm{M}$ ) was cumulatively applied after the control oscillating inward currents (upper) were observed. A short rectangular pulse $(-1 \mathrm{mV}, 4 \mathrm{~ms})$ was applied before and after the applications of $\mathrm{NiCl}_{2}(120 \mu \mathrm{M})$ to measure input resistance (B).

$0.4 \pm 7.3$ and $-5.4 \pm 8.6 \%$, respectively. This result suggested that L-type $\mathrm{Ca}^{2+}$ channels were not involved in the generation of inward current oscillation itself. When $10 \mu \mathrm{M}$ nifedipine was applied $(n=4)$, the amplitude of the inward currents was reduced by $30.7 \pm 13.2 \%$, as seen in Fig. $6 \mathrm{~d}$, but the frequency and $\mathrm{ICD}_{50}$ were relatively unchanged (by $-5.5 \pm 9.9$ and $-3.7 \pm 13.7 \%$, respectively). The suppression induced by nifedipine at concentrations greater than $10 \mu \mathrm{M}$, is consistent with the changes in slow wave amplitude measured microelectrodes in guinea pig stomach [16].

Low concentrations of $\mathrm{Ni}^{2+}(\sim 40 \mu \mathrm{M})$ are known to block T-type voltage-sensitive $\mathrm{Ca}^{2+}$ channels in cardiac pacemaker cells [17]. As shown in Fig. 7A, the applications of $40 \mu \mathrm{M} \mathrm{Ni}{ }^{2+}$, however, little affected oscillating inward currents in intestinal cell cluster preparations. When the concentration of $\mathrm{Ni}^{2+}$ was increased to $120 \mu \mathrm{M}$, the oscillating inward currents were significantly suppressed $(n=4)$. Figure 7B shows the membrane currents induced by applying a short rectangular pulse of $-1 \mathrm{mV}(4 \mathrm{~ms})$ : measurements of the input resistance. When $120 \mu \mathrm{M} \mathrm{Ni}^{2+}$ suppressed inward current oscillation, the input resistance increased by approximately $30 \%$. Moreover, an application of $100 \mu \mathrm{M} \mathrm{Cd}{ }^{2+}$ instead of $\mathrm{Ni}^{2+}$ almost completely blocked inward current oscillation $(n=4)$, as shown in Fig. 8. These results suggested that some cationic conductance, e.g., nonselective cation channels, may play an important role in intestinal tract pacemaking. 


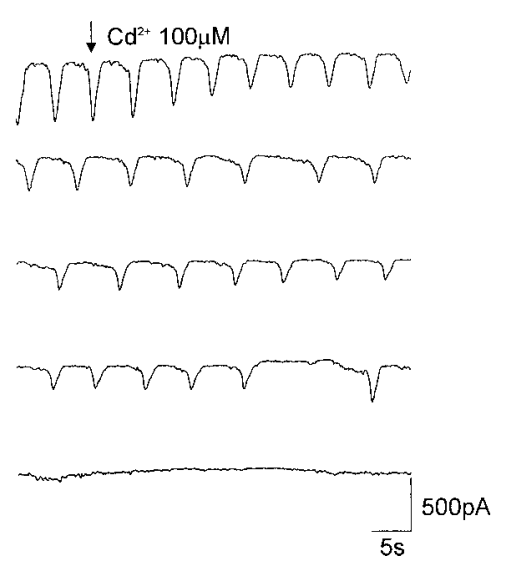

Fig. 8. Effects of $\mathbf{C d}^{2+}$. One hundred $\mu \mathrm{M} \mathrm{Cd}^{2+}$ was added to the bathing solution at the point indicated by the arrow. The time course of the termination of the oscillating inward current is shown in the following current traces.

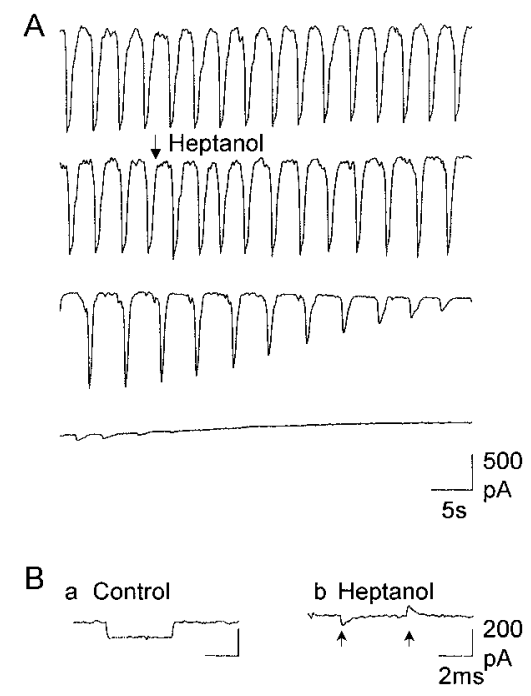

Fig. 9. Effects of heptanol. Five $\mu \mathrm{M}$ 1-heptanol was applied after observing control oscillations (A). In (B), the same rectangular pulse used in Fig. 7B was applied. Note the capacitive-surge-type transient currents (indicated by arrows) in the presence of heptanol.

In Fig. 9, we examined the effect of heptanol, a gap junction channel blocker (e.g., [18]). The applications of $3-10 \mathrm{mM}$ heptanol $(n=8)$ gradually reduced the amplitude of the oscillating inward current and altered its interval before termination of the spontaneous activity. Figure 9A shows that the inward current oscillation ceased 2-3 min after an application of $5 \mathrm{mM}$ heptanol. This treatment also completely suppressed spontaneous rhythmic contraction. Figure 9B shows the measurements of input resistance in the same cell examined in Fig. 9A. The same rectangular pulse protocol in Fig. 7B was used. The application of heptanol $(5 \mathrm{mM})$ significantly increased the input resistance (from $15.9 \mathrm{M} \Omega$ to an unmeasurable level); conse- quently a capacitive transient current appeared, indicating a disconnection of electrical coupling. The membrane capacitance of the cell estimated by integrating the capacitive currents recorded during exposure to $5 \mathrm{mM}$ heptanol was $27.3 \pm 4.8 \mathrm{pF}(n=4)$.

\section{DISCUSSION}

During culture for several days, spontaneous contractions were observed in many cell clusters isolated from the muscle layer of mouse small intestine, including myenteric plexus. Thus it was easy to find cell clusters that would show electrical activity in patch clamping. The disadvantage of this method was the technical difficulty in recording electrical activity because of contractions. On the other hand, in our preliminary experiments only a few c-Kit-immunopositive cells showed spontaneous electrical activity when they were isolated.

c-Kit-positive interstitial cells are often called ICC, and are considered to play critical roles in basic functions in gastrointestinal motility, such as the generation and propagation of electrical pacemaker activity (e.g., [5-7]). In the present study, immunohistochemistry revealed that networks of c-Kit-positive interstitial cells were included in the cultured cell clusters (Fig. 2B). This preparation also included enteric neurones and smooth muscle cells (Figs. 2F and 3). It is considered that the enteric neurones play an important role in modulating the basic rhythmicity and interacting adjacent contractile units $[19,20]$. It seems that the cell cluster preparation newly developed in the present study consists of the essential minimum cell members necessary for the investigation of the underlying mechanisms of intestinal motility and pacemaker function. Furthermore, a high immunoreactivity of anticonnexin antibody distributed over the cluster implies that the whole-cell cluster acts as an electric syncytium. Using a video camera system, we observed synchronized spontaneous contractions over the cell cluster.

By the use of whole-cell patch clamp techniques, inward current oscillations were recorded from the intestinal cells near the edge of the cell cluster. Although not all cells used for electrical measurements were identified immunohistochemically with anti- $\gamma$ enteric actin antibody, most were presumed to be smooth muscle: some of them were clearly contracting. The inward current oscillations are considered to correspond to slow-wave activity. Since a great many gap junction channels is expressed up to several days after culture (Fig. 2C), electrical events would be easily conducted over the cluster. Also, in gastrointestinal 
smooth muscle the presence of gap junction channel families between smooth muscle cells and between smooth muscle and putative pacemaker cells has been shown (e.g., [21-23]. In our cell cluster preparations, the amplitude of oscillating inward current varied considerably. This may be due to differences in the distances between pacemaker cells and the cells tested. In canine colon, an analogous phenomenon has been reported: The amplitude of slow waves is maximal near the submucosal surface, a putative pacemaker region, and decreases as the recording electrode gets farther from the region [24, 25].

The oscillating inward currents in the cultured cell clusters and slow waves recorded in the intact tissue share three characteristic features. (1) TTX resistance (Fig. 6b) suggests that intrinsic neurones are not involved in their generation. (2) Dihydropyridine $\mathrm{Ca}^{2+}$ channel blockers little affect the frequency of inward current oscillation (Fig. 6c and d), though contraction was suppressed (data not shown). This suggests that smooth muscle L-type $\mathrm{Ca}^{2+}$ channels $\left(\alpha_{1 \mathrm{C}-\mathrm{b}}\right)$ contribute mainly to sustained $\mathrm{Ca}^{2+}$ influx (noninactivating $\mathrm{Ca}^{2+}$ current [26-28]) during the depolarization phase of slow waves, but little to pacemaker activity. (3) High-temperature dependence suggests an involvement of some metabolism-dependent processes $[1,29]$. The cell cluster preparation thus seems to be a good model system for the investigation of slow wave generation. Further, the correlation plot between the oscillation frequency and cluster size (Fig. 5A) suggests that the minimum unit of small intestinal tissue that can reproduce normal slow waves is less than $100 \mu \mathrm{m}$ in diameter.

It is well known that low concentrations $(\sim 40 \mu \mathrm{M})$ of $\mathrm{Ni}^{2+}$ selectively inhibit classical T-type $\mathrm{Ca}^{2+}$ channels (low-voltage-activated $\mathrm{Ca}^{2+}$ channels), which play an important role in cardiac pacemaker cells [17]. We also previously examined properties of slow waves in the circular smooth muscle layer isolated from guinea pig stomach. Lower concentrations $(<10 \mu \mathrm{M})$ of $\mathrm{Ni}^{2+}$ significantly suppressed slow waves in this preparation, where myenteric plexus was not included [16]. In the present study, $\mathrm{Ni}^{2+}$ at such low concentrations little affected oscillating inward currents, which are considered to correspond to slowwave activity (Fig. 7). However, relatively high concentrations of $\mathrm{Ni}^{2+}(120 \mu \mathrm{M})$ and $\mathrm{Cd}^{2+}(100 \mu \mathrm{M})$ significantly suppressed oscillating inward currents. These results suggest that some cation channels, other than L-type and classical T-type $\mathrm{Ca}^{2+}$ channels, played an important role in pacemaking in the cell cluster preparation that included myenteric plexus and c-Kit-positive interstitial cells. Recently, RT-PCR (re- verse-transcription polymerase chain reaction) studies have revealed that ICC (determined with c-Kit-immunoreactivity) and smooth muscle cells in mouse small intestine both express the trp (transient receptor potential) gene family (trp4 and $\operatorname{trp} 6$ ), which is considered to form nonselective cation channels and to store-operated $\mathrm{Ca}^{2+}$ channels [30].

In murine colonic smooth muscle, a novel low-voltage-activated current has been reported very recently [31]. This current is resistant to dihydropyridine $\mathrm{Ca}^{2+}$ antagonist, but it is also permeable to $\mathrm{Na}^{+}$, unlike Ttype $\mathrm{Ca}^{2+}$ channel currents. These novel low-voltage-activated, nonselective cation channels might be expressed in the cell clusters used in the present study. This ionic conductance, however, does not seem to contribute much to spontaneous rhythmicity in the cell clusters because of its high sensitivity to $\mathrm{Ni}^{2+}$ $\left(\mathrm{IC}_{50}=14 \mu \mathrm{M}\right)$. It has also been shown that T-type (low-voltage-activated) $\mathrm{Ca}^{2+}$ channels are categorized into molecular subclasses. One of the T-type $\mathrm{Ca}^{2+}$ channels $\left(\alpha_{1 \mathrm{G}}\right)$ requires high concentrations of $\mathrm{Ni}^{2+}$ to be blocked $\left(\mathrm{IC}_{50}=0.5-1.1 \mathrm{mM}\right.$ [32]). The possibility that low-voltage-activated $\mathrm{Ca}^{2+}$ channels with similar $\mathrm{Ni}^{2+}$ sensitivity may play an important role in pacemaking still remains.

In the presence of $120 \mu \mathrm{M} \mathrm{Ni}^{2+}$, the input resistance measured by applying rectangular pulse was slightly increased (Fig. 7B). This is probably due to a partial inhibition of ionic conductances in the plasma membrane of clustered cells electrically connected by gap junctions. On the other hand, heptanol nearly completely blocked the cell-to-cell electrical connection via gap junction channels (Fig. 9B) and suppressed the electrical and mechanical activities in the cell cluster. Before terminating inward current oscillation, the interval of the inward current became irregular in the presence of this drug (Fig. 9A). From this result it can be speculated that an electrical coupling of intestinal cells itself may make some contribution to pacemaker activity.

Several papers have appeared recently reporting electrical properties of isolated ICC (c-Kit-immunopositive cells) and pacemaker cells (driving cells; ICC) in the tissue. The pacemaker (driving) potential recorded from driving cells in stomach smooth muscle tissue is very large, reaching up to $50 \mathrm{mV}$ [33]. On the other hand, in isolated ICC from small intestine [8-10] the amplitude of the oscillating current is usually small $(\sim 30 \mathrm{pA}$, which is even smaller than that recorded from smooth muscle cells in the present study), and the frequency is irregular. Taken together, these results suggest that the electrical behavior of isolated ICC alone may not accurately re- 
flect the ICC properties in intact tissue and that how ICC and other members of intestinal cells are assembled and coordinated may be important. Cell cluster preparations could be used for linking studies performed on isolated cells and on intact tissues.

It has also been reported previously that c-Kit-immunopositive precursor cells differentiate to ICC (cKit positive) and smooth muscle cells (c-Kit negative) and that electrical rhythmicity appears in gastrointestinal tissues $[34,35]$. These observations reinforce the hypothesis of ICC as pacemaker cells and may also suggest the possibility that the interaction of ICC and smooth muscle is an important factor. Furthermore, periodic depolarizations are still observed in isolated circular muscle from the stomach (with no myenteric plexus where ICC are abundant), though the voltage dependence of the periodic depolarizations is altered by this isolation procedure [16]. The circular muscle layer also includes intramuscular interstitial cells (ICIM), which are c-Kit-immunopositive. However, the number of these cells is much lower than in smooth muscle tissue including myenteric plexus. These facts prompt further speculation that even though ICC in the myenteric plexus are pacemaking, some coordinating actions along with smooth muscle cells, such as regenerating potentials seen in isolated circular muscle bundles of guinea pig stomach [36, 37], may be essential in normal electrical oscillation.

In conclusion, we have developed a new preparation that could be used as a model system to investigate underlying mechanisms of intestinal motility. Patch clamp and other electrophysiological techniques can be applied to this preparation. The minimum intestinal unit to generate normal spontaneous activity is approximately $100 \mu \mathrm{m}$ or less in diameter. The applications of channel blocking agents suggest that $\mathrm{Ca}^{2+}$ influx pathways other than L-type and classical T-type $\mathrm{Ca}^{2+}$ channels play an important role in pacemaking: e.g., nonselective cation channels, store-operated $\mathrm{Ca}^{2+}$ channels, and new type low-voltage-activated $\mathrm{Ca}^{2+}$ channels. Cell-to-cell electrical coupling may also make some contribution.

The authors are grateful to Drs. Andrew J. Cook (University of Westminster, UK) and Kenji Wakai (Nagoya University, Japan) for their useful discussion and improvements to the manuscript. This work was partly supported by a Grant-inAid for Scientific Research from the Ministry of Education, Science, Sports and Culture, Japan.

\section{REFERENCES}

1. Tomita T: Electrical activity (spikes and slow waves) in gastrointestinal smooth muscle. In: Smooth Muscle: An
Assessment of Current Knowledge, ed Bülbring $E$, Brading AF, Jones AW, and Tomita T, Edward Arnold, London, pp 127-156, 1981

2. Szurszewski JH: Electrical basis for gastrointestinal motility. In: Handbook of the Gastrointestinal Tract, 2nd ed, ed. Johnson LR, Ravan Press, New York, pp 383-422, 1987

3. Sanders KM: Ionic mechanisms of electrical rhythmicity in gastrointestinal smooth muscles. Annu Rev Physiol 54: 439-453, 1992

4. Suzuki $\mathrm{H}$ : Cellular mechanisms of myogenic activity in gastric smooth muscle. Jpn J Physiol 50: 289-301, 2000

5. Ward SM, Burns AJ, Torihashi S, and Sanders KM: Mutation of the proto-oncogene c-kit blocks development of interstitial cells and electrical rhythmicity in murine intestine. J Physiol (Lond) 480: 91-97, 1994

6. Huizinga JD, Thurneberg L, Klüppel M, Malysz J, Mikkelsen $\mathrm{HB}$, and Bernstein $\mathrm{A}$ : W/kit gene required for interstitial cells of Cajal and for intestinal pacemaker activity. Nature 373: 347-349, 1995

7. Torihashi S, Ward SM, Nishikawa S-I, Nishi K, Kobayashi S, and Sanders KM: C-kit-dependent development of interstitial cells and electrical activity in the murine gastrointestinal tract. Cell Tissue Res 280: 97-111, 1995

8. Tokutomi N, Maeda H, Tokutomi Y, Sato D, Sugita M, Nishikawa S, Nishikawa S, Nakao J, Imamura T, and Nishi K: Rhythmic $\mathrm{Cl}^{-}$current and physiological roles of the intestinal c-kit-positive cells. Pflügers Arch 431: 169-177, 1995

9. Koh SD, Sanders KM, and Ward SM: Spontaneous electrical rhythmicity in cultured interstitial cells of Cajal from the murine small intestine. J Physiol (Lond) 513: 203-213, 1998

10. Thomsen L, Robinson TL, Lee JCF, Farraway LA, Hughes MJG, Andrews DW, and Huizinga JD: Interstitial cells of Cajal generate a rhythmic pacemaker current. Nature Med 4: 848-851, 1998

11. Klemm MF, Exintaris B, and Lang RJ: Identification of the cells underlying pacemaker activity in the guineapig upper urinary tract. J Physiol (Lond) 519: 867-884, 1999

12. Sergeant GP, Hollywood MA, McCloskey KD, Thornbury KD, and McHale NG: Specialised pacemaking cells in the rabbit urethra. J Physiol (Lond) 526: 359-366, 2000

13. Nakayama $S$, and Brading AF: Evidence for multiple open states of the $\mathrm{Ca}^{2+}$ channels in smooth muscle cells isolated from the guinea-pig detrusor. J Physiol (Lond) 471: 87-105, 1993

14. Schuster A, Lacinová L, Klugbauer N, Ito H, Birnbaumer L, and Hofmann F: The IVS6 segment of the Ltype calcium channel is critical for the action of dihydropyridines and phenylalkylamines. EMBO $J$ 15: 2365-2370, 1996

15. Horowitz B, Ward SM, and Sanders KM: Cellular and molecular basis for electrical rhythmicity in gastrointestinal muscles. Annu Rev Physiol 61: 19-43, 1999

16. Huang S-M, Nakayama S, lino S, and Tomita T: Voltage sensitivity of slow wave frequency in isolated circular muscle strips from guinea pig gastric antrum. Am J 
Physiol 276: G518-G528, 1999

17. Hagiwara K, Irisawa $\mathrm{H}$, and Kameyama M: Contribution of two types of calcium currents to the pacemaker potentials of rabbit sino-atrial node cells. J Physiol (Lond) 395: 233-253, 1988

18. Bernardini G, Peracchia C, and Peracchia LL: Reversible effects of heptanol on gap junction structure and cell-to-cell electrical coupling. Eur J Cell Biol 34: 307-312, 1984

19. Stevens RJ, Publicover NG, and Smith TK: Induction and organization of $\mathrm{Ca}^{2+}$ waves by enteric nervous reflexes. Nature 399: 62-66, 1999

20. Stevens RJ, Publicover NG, and Smith TK: Propagation and neural regulation of calcium waves in longitudinal and circular muscle layers of guinea-pig small intestine. Gastroenterology 118: 892-904, 2000

21. Nakamura K, Kuraoka A, Kawabuchi M, and Shibata Y: Specific localization of gap junction protein, connexin 45 , in the deep muscular plexus of dog and rat small intestine. Cell Tissue Res 292: 487-494, 1998

22. Nakamura $\mathrm{K}$ and Shibata $\mathrm{Y}$ : Connexin 43 expression in network-forming cells at the submucosal-muscular border of guinea pig and dog colon. Cells Tissues Organs 165: 16-21, 1999

23. Daniel EE and Wang YF: Gap junctions in intestinal smooth muscle and interstitial cells of Cajal. Microsc Res Tech 47: 309-320, 1999

24. Smith TK, Reed JB, and Sanders KM: Origin and propagation of electrical slow waves in circular muscle of canine proximal colon. Am J Physiol 252: C215-C224, 1987

25. Liu LWC and Huizinga JD: Electrical coupling of circular muscle to longitudinal muscle and interstitial cells of Cajal in canine colon. J Physiol (Lond) 470: 445-461, 1993

26. Imaizumi Y, Muraki K, and Watanabe M: Measurement of noninactivating $\mathrm{Ca}$ current in smooth muscle cells. Methods Neurosci 4: 44-60, 1991

27. Nakayama $S$ and Brading AF: Possible contribution of long open state to non-inactivating $\mathrm{Ca}$ current in detrusor cells. Am J Physiol 269: C48-C54, 1995
28. Nakayama S, Klugbauer N, Kabeya Y, Smith LM, Hofmann $F$, and Kuzuya $M: \alpha_{1}$-Subunit of smooth muscle $\mathrm{Ca}^{2+}$ channel preserves multiple open states induced by depolarization. J Physiol (Lond) 526: 47-56, 2000

29. Nakayama S, Chihara S, Clark JF, Huang S-M, Horiuchi $\mathrm{T}$, and Tomita $\mathrm{T}$ : Consequences of metabolic inhibition in smooth muscle isolated from guinea-pig stomach. J Physiol (Lond) 505: 229-240, 1997

30. Epperson A, Hatton WJ, Callaghan B, Doherty $P$, Walker RL, Sanders KM, Ward SM, and Horowitz B: Molecular markers expressed in cultured and freshly isolated interstitial cells of Cajal. Am J Physiol 279: C529-C539, 2000

31. Koh SD, Monaghan K, Ro S, Mason HS, Kenyon JL, and Sanders KM: Novel voltage-dependent non-selective cation conductance in murine colonic myocytes. J Physiol (Lond) 533: 341-355, 2001

32. Lacinova L, Klugbauer N, and Hofmann F: Regulation of the calcium channel alpha(1G) subunit by divalent cations and organic blockers. Neuropharmacology 39: 1254-1266, 2000

33. Dickens EJ, Hirst GDS, and Tomita T: Identification of rhythmically active cells in guinea-pig stomach. J Physiol (Lond) 514: 515-531, 1999

34. Torihashi S, Ward SM, and Sanders KM: Development of c-Kit-positive cells and the onset of electrical rhythmicity in murine small intestine. Gastroenterology 112: 144-155, 1997

35. Torihashi S, Nishi K, Tokutomi Y, Nishi T, Ward S, and Sanders KM: Blockade of Kit signalling induces transdifferentiation of interstitial cells of Cajal to a smooth muscle. Gastroenterology 117: 140-148, 1999

36. Suzuki $H$ and Hirst GDS: Regenerative potentials evoked in circular smooth muscle of the antral region of guinea-pig stomach. J Physiol (Lond) 517: 563-573, 1999

37. Edwards FR, Hirst GDS, and Suzuki H: Unitary nature of regenerative potentials recorded from circular muscle of guinea-pig antrum. J Physiol (Lond) 519: 235250, 1999 